\title{
Sustainable Development Perspectives for Latvian Regions
}

\author{
Anna Ābeltiņa, Rosita Zvirgzdiṇa, Vita Zariṇa \\ Turiba University, Faculty of Business Administration. \\ Address: Graudu street 68, Riga, LV-1058, Latvia
}

\begin{abstract}
Regional economies is a relatively young branch of economics, whose theoretical aspects started to develop in the 20s and 30s of the previous century, but gained vivid manifestation in the EU Regional policy. Since the Rome Treaty (1957), the need for a coordinated community solution to regional problems and the correction of regional imbalances was also recognised in EU political documents. The end of the twentieth century was the beginning of important international political processes marked by the start of a new way of thinking. This new way was sustainable development. Sustainable development is a concept that has to combine economic growth with such a use of natural resources that benefits the society as a whole. The long-term development has three dimensions: environmental, economic and social. In this paper, the attention will be paid to relationship between these dimensions and the regional development.

The aim of this paper is to take a closer look at the consideration of a new viewpoint, as it may seem, related to well-known things that deal with such economic concepts as regional development and sustainable development and evaluation of specifics of sustainable development in Latvian regions. To achieve the aim, the following tasks were selected: to examine the theoretical background and regional development preconditions of sustainable development; to analyse the present specifics of Latvian regions in the context of sustainable development; to consider future developments from the viewpoint of facilitation of sustainable regional development. The following research methodology was used: literature review, graphical method, focus group discussions and logically constructive approach - for making judgements and result analysis; synthesis method - to combine the elements in a unified system; social research methods - to obtain the primary information and to carry out its verification. Conclusions: the main reasons for misbalanced regional development are the differences in employment, levels of income and investment. The research proposes solutions to promote balanced regional development.
\end{abstract}

Keywords: regional development, sustainable development, economic indicators.

\section{INTRODUCTION}

The Baltic region belongs to the regions that develop very quickly thanks its place at the crossroads of international trade and therefore attracts a considerable interest in business environment that should be used appropriately. The East European countries, including also Latvia, regained independence only in the end of the $20^{\text {th }}$ century, and were forced to get involved into an inexorable competition. Latvia as a comparatively small country, possessing not considerable natural resources, is obliged to make use of all its intellectual resources, knowledge, human capital, and innovations to be able to compete in the global world and provide a sustainable development.

The adequate national regional policy becomes formed in Latvia, and it is aimed to create a balance in development levels all over the territory of the country, taking into consideration the basic principles of the regional policy of the European Union that defines the general framework of creation and implementation of regional policy in the Community.

The regional policy of the European Union is based on such values as solidarity and cohesion. In the TITLE XVII - Economic and social cohesion in Consolidated Version of the Treaty Establishing the European Community we can read next "In order to promote its overall harmonious development, the Community shall develop and pursue its actions leading to the strengthening of its economic and social cohesion. In particular, the Community shall aim at reducing disparities between the levels of development of the various regions and the backwardness of the least favoured regions or islands, including rural areas" [1]. A successful regional development may be achieved, when approach to it takes place through a complex and aimed to sustainability process.

Sustainable development has been defined in many ways, but the most frequently quoted definition is from Our Common Future, also known as the Bruntland Report: "Sustainable development is 
development that meets the needs of the present without compromising the ability of future generations to meet their own needs" [2]. It is generally accepted that there are three dimensions or pillars of a sustainable development: environmental or ecological, economic, and social and cultural.

The environmental or ecological pillar is related to substitution of non-renewable resources with renewable resources, to preserving of a healthy natural environment, providing of physical and intellectual health. The economic pillar has to provide economic growth, efficiency, stability, development, welfare, not forgetting at the same time about protection of environment, because exactly the environment forms the basis of support for other pillars. And, lastly, the social and cultural pillar has to provide social peace, united society, social justice, opportunities of education and development for people. Actually, we can recognize that the aim of a sustainable development is the improvement of the quality of life, developing the economy (instrument, with the help of which we can achieve the aim) in the framework of the renewable ability of the ecosystem (environment as basis for sustainable development). There should be paid attention to the culture aspect, because under conditions of the globalisation it is, exactly, the one that is regarded as one of the most essential elements favourable to wholesome existence. The research of the European Union "Sustainable Development in the Multi-shaped World" accentuates even that a mutual existence of different cultures may create the basis for development, because it facilitates maintaining of traditions as the main link between the healthy past and the possible future [3]. A high level stable social and cultural system means that in the centre of sustainable development there are exactly people, having a healthy and productive life in harmony with the environment.

Therefore, to provide that the development might be sustainable, it is necessary to keep balance between economic, social and environmental pillars, increasing getting of benefits in the present in such way that also the following generations would be able to provide their needs. And in this context, the sustainable development is one of the main challenges of the EU. Accordingly, it is understandable that in the future, it will be impossible to solve the problems of sustainability without developed sciences, without a sufficient knowledge about environment, economy and social aspects, and also without active participation of the population able to manage the implementation of the principles of sustainability. It may be added that some authors have remarked that the viewpoints related to the growth and development have changed. The new paradigm of sustainable development is based on the following preconditions:

1. the goal of viable, long-term growth;
2. conserving resources in production through energy efficient technologies and dispersed production centres of lesser scale;

3. a shift towards alternative energy sources, recycling and conservation of resources

4. the assumption that humans and the environment are mutually independent, acknowledgment that resources are exhaustible and often irreplaceable, and that conservation is a principle for long-term viability.

Sustainable development may be seen as improving the economy without undermining the environment of society [4].

Nowadays no one theory adequately or totally explains regional economic development, but we can say that the sum of different theories show as next important factors what promote development. This factors are: natural resources; labor; capital; investment; entrepreneurship; transport; communication; industrial composition; technology; size; export market; international economic situation; local institutional capacity; national, local and state government spending; development support schemes [4]. In different cases different factors has greatest weight. In our research we pay attention to relationship between the mentioned dimensions and regional development specifics. [4].

\section{RESULTS AND DISCUSSION}

Sustainable development in Latvia and its regions, proclaimed to be oriented to the meeting of the needs today and to the ability to provide that the future generations can meet their needs, as well as to the keeping of the balance between economic, social and environmental pillars related to and depending on the actual social economic level and the tendencies of its changes, cannot be regarded as satisfactory and sufficient. It may be seen demonstratively, if the social economic situation in Latvia becomes compared with the developments and results achieved by other member states of the EU and its regions, as well as on the basis of a mutual comparison of Latvian regions.

In spite of continuous activities and regular measures aimed to achieve a higher economic growth and increase of the productivity, Latvia has, up to now, succeeded less than planned and ranks low among the other member states of the EU. According to the GDP per capita, Latvia in 2012, along with Poland, Hungary and Croatia, belonged to the countries, the GDP of which made less than 40 percent below the EU-28. The GDP per capita in Latvia in 2013 was 2 times lesser than in Netherlands, 1.9 times lesser than in Denmark and 1.8 times lesser than in Finland [12].

Similarly, the low labour productivity spread across eastern and northern Europe and being typical to the regions of Bulgaria and Hungary, to all Baltic States, 
to the regions of Poland and Romania, except the capital regions of Mazowieckie and Bucuresti-lifow, to four regions from the Czech Republic and two regions from Slovakia, makes lesser than 50 percent of the EU-28 average.

As it might be expected, the individual consumption, being related closely to the production level, was in 2013 in Latvia actually 1.7 times lesser than in Netherlands, Denmark and Finland.

As to the price level, the highest is typical to Denmark among the Member States, and it makes 42 percent above the EU-28 average. To other countries with the price levels more than 20 percent of the EU28 average belong Sweden, Luxemburg, Finland and Ireland. The price levels in Belgium, the Netherlands, the United Kingdom, Austria and France are between 10 and 15 percent above the average. Italy and Germany have price levels of less than 5 percent above the EU-28 average. At the lower end of that table, may be found several Member States with price levels less than 40 percent below the EU-28 average: Latvia, the Czech Republic Slovakia and Croatia, followed by Lithuania, Hungary and Poland with price levels less than 50 percent. The lowest price levels half the EU average and below - are typical to Romania, Albania and Bulgaria.

The economic, social and environmental development of every region depends on the density of population. In 2012 , the EU-28 population density was estimated at 116.3 inhabitants per square kilometre. There were 117 NUTS 3 regions in the EU where the population fell. These regions were largely spread across: the Baltic Member States of Lithuania and Latvia; an arc in south-east Europe, starting in Croatia and moving through Hungary, Romania, Bulgaria and down into Greece; several inland regions of Portugal and Spain; and many eastern German regions. The biggest reduction of population (20.8 per thousand inhabitants per year) was registered in the Lithuanian region of Šiauliu apskritis, while Utenos apskritis was the only other region, which population declined by at least 20.0 per thousand inhabitants per year.

There were 481 NUTS 3 regions in the EU-28, where net migration during the period 2008-2012 was negative. These were spread across much of eastern Europe (particularly Bulgaria, Hungary, Poland and Romania), as well as across Latvia, Lithuania, eastern Germany north-eastern France, pockets of Spain and the southern and western regions of Ireland. The 14 NUTS 3 regions with the biggest negative crude rates of net migration featured 9 of the 10 regions contained within Lithuania. Population levels are also in decline across much in Bulgaria, Greece, Spain, Croatia, Hungary, Poland, Portugal, Romania and the Baltic Member States as a result of natural population decline - however, this development is often accentuated by net emigration, which has been particularly apparent in some regions following the financial and economic crisis.

The causes of the low position of Latvia among the other member states of the EU are sought in unbalanced development of the regions in our country. There are considerable disparities in social economic development between the regions. And these disparities turn out as being rather stable, without tending to diminish [10].

As the most unfavourable development factor has become the changes in the number of population (Fig. $1)$.

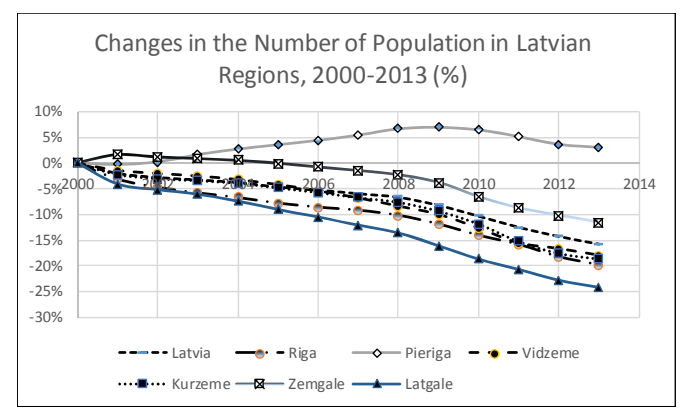

Fig. 1. Changes in the Number of Population in Latvian Regions, 2000-2013

As it is seen from the data in figure 1, during the period 2000-2013, Latvia has experienced a consequent gradual decrease in its population, having led to the loss of 15.9 percent of inhabitants in 2013. The situation in the regions differs. As to the proportion of the loss, Latgale has suffered mostly, having lost at the end of the period 24.2 percent of its inhabitants. Latgale is followed successively by Riga region (19.9 percent), Kurzeme region (18.6 percent), Vidzeme region (18.0 percent) and Zemgale region 11.6 percent). The only region that has showed a small increase in the number of population ( 3.0 percent) is the Pieriga region. The changes in the number of population are related to the emigration and the migration to other regions of Latvia, mainly to Riga and Pieriga region. The departing of native locations becomes explained, for the most part, on the basis of impossibility to find employment at all, to find a suitable employment and because of insufficient wages. And, usually, there are departing the more skilled and better trained workers, with remaining of the less skilled, that results sometimes in appearance of unfavourable structural changes in both the labour force and the population [5].

The wages (Fig. 2), being mentioned as one of the main factors, having accelerated the diminishing of the number of population in Latvia, are comparatively low, as it was seen if compared with the wages in other countries of the EU. 


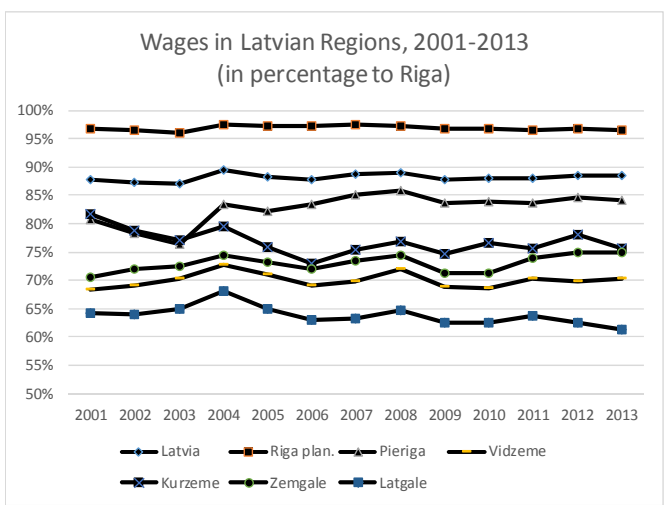

Fig. 2. Wages in Latvian Regions, 2001-2013

And being comparatively low as such, they show considerable disparities in Latvian regions. In comparison with the Riga region, the average of the wages fluctuates during the period 2001-2013: in Pieriga from 85.9 percent in 2008 to 82.3 percent in 2005 , in Vidzeme - from 72.8 percent in 2004 to 68.4 percent in 2001, in Kurzeme - from 87.2 percent in 2003 to 72.9 percent in 2006 , in Zemgale - from 75.0 percent to 70.6 percent in 2001, in Latgale - from 68.2 percent in 2004 to 61.4 percent in 2013. Such a rather low average of wages lets conclude that there is little place for savings.

At the same time, the income of the households depends mainly on the wages; therefore, as it may be expected, the distribution of the income has much in common with the level of the wages (Fig.3).

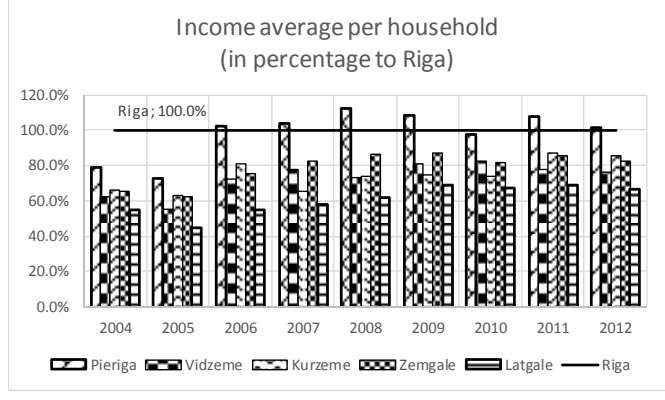

Fig.3. Income average per household

In comparison with the Riga region, the average of the income per household, during the period 20042012, has changed in Pieriga region from 112.6 percent in 2008 to 72.7 percent in 2005, in Vidzeme region - from 82.3 percent in 2010 to 55.6 percent in 2005, in Kurzeme region - from 86.8 percent in 2011 to 63.0 percent in 2005 , in Zemgale region - from 87.3 percent in 2009 to 62.6 percent in 2005 , in Latgale region - from 68.5 percent in 2009 to 44.9 percent in 2005. In all regions, the lowest level has taken place in 2005. Such disparities in the average of the income per household may turn out being critical for the families in the regions, where the average of the income per household is nearly two times or even by one third less than in the Riga region. Such families are subjected to the threat of poverty. To stand up to the poverty, people are seeking for additional work that, in its turn, may lead to the working of too long hours, to overstraining, and, as a result, to the changes in the health for the worse [13].

The development of the regions, the economic growth, being the basis of balanced and sustainable development, cannot be achieved without respective investments. However, as it is seen from the statistics, the distribution of the non-financial investments in Latvia is far from a desirable one (Fig. 4).

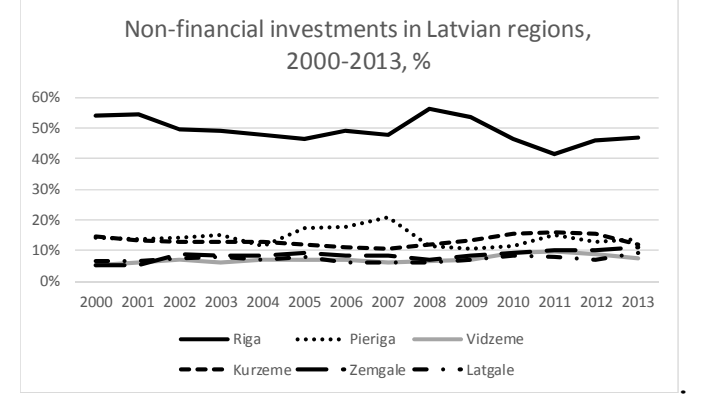

Fig. 4. Non-financial investments in Latvian regions, 200-2013

For the period 2000-2013, the proportion of investments received by Riga region, fluctuated from 56.4 percent in 2008 to 41.4 percent in 2011 , by Pieriga region - from 21.1 percent in 2007 to 10.7 percent in 2009, by Vidzeme region - from 9.2 percent in 2010 to 5.1 percent in 2000, Kurzeme region - from 15.9 percent in 2011 to 10,4 percent in 2007, Zemgale region - from 10.8 percent in 2013 to 5.4 percent in 2000, Latgale region - from 9.4 percent in 2013 to 6.1 percent in 2006 and 2008. The biggest sum of investments Riga region received in 2008 3935.5 million Euros, the smallest in 2010 - 1576.2 million Euros. Respective sums in Pieriga region were: 1479.6 million Euros in 2007 and 417.4 million Euros in 2000, in Vidzeme region - 471.9 million Euros in 2006 and 150.2 million Euros in 2000, Kurzeme region - 840 million Euros in 2008 and 421.6 million Euros in 2001, Zemgale region - 580.7 million Euros in 2007 and 158.2 million Euros in 2000, Latgale region - 478.5 million Euros in 2005 and 193.6 million Euros in 2000.

Regional disparities and their negative impact on sustainable development in Latvia, being the subject of studies and researches for a long time, have led to discussions of different approaches and ways aimed to finding out of solutions how to overcome the unbalanced development in Latvian regions. The most discussed problems relate to what kind of historical, traditional and nowadays situations and circumstances have caused and continue to cause the present situation, being so unfavourable to social development in Latvia and, especially to its regions, and, naturally, what must be done to overcome this situation, being so unfavourable to Latvia's development. In these 
discussions, as preconditions, favourable to sustainable development of rural regions, turned out, among others in a rather vast complex, a developed entrepreneurship, a common methodological research approach to economic growth in Latvian regions, a distribution of funds in the regions according to the principle of fairness, a polycentric principle in attraction and distribution of investments in Latvian regions, an increasing role of local governments in formation of infrastructure, a growing employment and income of households facilitated by development of entrepreneurship [11].

The theoretical concepts, research results and discussions created the basis for finding of some conceptual approaches that may be taken as basics in further researches in development of regions in Latvia. To find out related to it priorities, there were carried out interviews with experts (Dr.oec. S. Keišs, Dr.oec. H. Jirgena, Dr.oec. M. Pelše, Dr.oec. Dz. Atstāja, MBA A. Vanags). The following topics were chosen and discussed: infrastructure, increase of household income, attraction of investments, initiatives of local governments, long-term planning, problems to be researched.

The infrastructure is a priority and an urgent problem that requires to be solved more in the interests of Latvian inhabitants all over the territory of the country. It is necessary to combine the local needs with others, for example with the Rail Baltica. At the same time, it must be taken into consideration that local governments have their own needs. It has been proposed that it would be advisable, in this context, to pay more attention to the polycentric development idea, however, it has remained on a too general discussion level, and, up to now, is without a sufficient answer. The specific of the needs of local governments require a well developed planning and honest distribution of funds, a suitable inventory and control mechanism. Much depends of possible structural reforms, change of social support system, and potential regional development with attraction of investments. And as the main aim there must be a simultaneous facilitating of entrepreneurship, involving of new enterprises, so increasing the employment and income of inhabitants, and, as a result, increase of tax revenues.

It is clear that development of infrastructure is related closely to welfare of people and income of households. With the increase of the wages in the country, the income will increase to a degree also in the regions. However, the fact that there will be a difference in the wages is unavoidable. It takes place also in other countries, but it is essential to decrease this disparity. It may be achieved, facilitating the entry of enterprises into regions, which produce with a higher added value, produce innovative products, facilitate tourism development in the regions, improving, adding to tourism supply choice, developing the entrepreneurship: with decreased taxes and long-term policy of entrepreneurship development, and with a favourable entrepreneurship environment. The present situation is far from facilitating of seeking for employment, if only it is possible to receive support and social support. An acceptable pension is necessary to provide that old people can leave their working place for the new generation. The money must be created, but not consumed.

As to the attraction of investments to regions, there is not to be expected that foreign investors will be interested in, except Riga, Riga area, Jurmala, Liepaja, Ventspils and, perhaps, Daugavpils. All is depending on businesspeople, seeking for opportunities to develop production objects with the aim to attract foreign investors or to sale the objects profitably. It means that local governments have to use every opportunity to apply their initiatives and resources, trying to find and keep qualified specialists. Further, attention must be paid to the problem that sustainable economic growth is based on strong, patriotic families. The problem of improvement of gene pool is not solved, respectively, with motivation of demographic situation facilitate directly for educated people and persons, being already tax payers (involved in social insurance system of the country). Therefore, it is essential to speak about it, how important it is to provide "rooting" of specialists in the regions. One of important ways there might be the cooperation with entrepreneurs.

It is important to orient the local government initiatives to diminishing of the gap between the administrative territorial units, receiving the lion share of support and the others, less developed territories of the counties. It may be facilitated by serious arrangements such as cooperation between the local governments, between the local governments and the ministries, and between the ministries. If the ministries will not be interested in to facilitate the activities of subjected enterprises in remote territories of the country, then it will be difficult to achieve a certain result. The balanced development of regions requires finishing of the started reform that, during the more than a ten-year period has remained unfinished. With planning coming from above, the initiatives from below must not be left understated. And they may find their place in patriotic upbringing, structural reforms, support to regional entrepreneurship, tax reliefs, cooperation with young, with entrepreneur, monitoring of the needs of enterprises, and actively work with the projects of the EU, related to increase of wages and building of infrastructure.

In the long-term planning, the principal task is to find ways, how to counteract the emigration and migration of population, leading to diminishing of the number of inhabitants, especially in the rural regions, to losing of the working force, the young going to 
foreign universities, mostly without aim to return to the native country. One of the ways in this context is to be sought in a considerate structural reform facilitating the attraction of investments for development of business in a long-term period, developing in the regions the ability to attract new, knowledgeable, wanting to work inhabitants, against offering a territory with clean air, water, picturesque and esthetical environment. An important role there may be played by differentiated reliefs for enterprise income tax, for example, on the basis: entrepreneurs $>$ $100 \mathrm{~km}$ from Riga $>200 \mathrm{~km}$ from Riga.

To the tendencies that should be researched in the future to perceive the changes, taking place in social economic development on the local level in rural areas in the context of the research results must be ascribed the social dimension, focusing on primary needs of the people, the environmental dimension, oriented directly to the welfare of the people, being situated on the lowest level, and the economic dimension, reflected through satisfaction with the services received by inhabitants. But it requires adequate information about the changes in the number of inhabitants and the capital, in the GDP, employment, income and others. For regional structural analysis of especial importance will be: age, education, potential working opportunities, employment, insurance, income, credit reliabilities to show the tendencies and allow prognosticate the future. And it depends, a great deal, on the information possible to receive from the Central Statistical Bureau of the Republic of Latvia. The quality of expected research results will be related closely to the timeliness and fullness in reflection of the changes in administrative territorial formations by statistical data.

\section{CONCLUSION}

Regional disparities and their negative impact on sustainable development in Latvia is the subject of studies and researches for a long time. There had been discussed different approaches and ways aimed to finding out of solutions how to overcome the unbalanced development of Latvian regions.

The theoretical concepts, research results and discussions created the basis for finding of some conceptual approaches that may be taken as basics in further researches in development of regions in Latvia, such as infrastructure, increase of household income, attraction of investments, initiatives of local governments, long-term planning, problems to be researched.

The specific of the needs of local governments require a well developed planning and honest distribution of funds, a suitable inventory and control mechanism. Much depends of possible structural reforms, change of social support system, and potential regional development with attraction of investments.

The increase in household income may be achieved, facilitating the entry of enterprises into regions, which produce with a higher added value, produce innovative products, facilitate tourism development in the regions.

As to the attraction of investments to regions, there is not to be expected that foreign investors will be interested in, except Riga, Riga area, Jurmala, Liepaja, Ventspils and, perhaps, Daugavpils. All is depending on businesspeople, seeking for opportunities to develop production objects with the aim to attract foreign investors or to sale the objects profitably.

It is important to orient the local government initiatives to diminishing of the gap between the administrative territorial units, receiving the lion share of support and the others, less developed territories of the counties. It may be facilitated by serious arrangements such as cooperation between the local governments, between the local governments and the ministries, and between the ministries.

In the long-term planning, the principal task is to find ways, how to counteract the emigration and migration of population, leading to diminishing of the number of inhabitants, especially in the rural regions, to losing of the working force, the young going to foreign universities, mostly without aim to return to the native country.

To the tendencies that should be researched in the future to perceive the changes, taking place in social economic development on the local level in rural areas.

\section{REFERENCES}

[1] European Union Consolidated Treaties Treaty on European Union Treaty establishing the European Community Luxembourg: Office for Official Publications of the European Communities 1997 - 168 pp. ISBN 92-828-16400 [Online]. Available: http://www1.umn.edu/humanrts/instree/EUAmsterdamtreaty.pdf [Accessed: Jan.13, 2015]

[2] Report of the World Commission on Environment and Development: Our Common Future. Chapter 2: Towards Sustainable Development. [Online]. Available: http://www.un-documents.net/our-common-future.pdf [Accessed: Dec. 16, 2014]

[3] Sustainable development in a diverse world (Sus.Div) Position paper of research task 1.2. Cultural diversity as an asset for human welfare and development [Online]. Available:

http://www.academia.edu/4367069/Sustainable_Developmen $\mathrm{t}$ in_a Diverse World_SUS.DIV_POSITION_PAPER_OF RESEARCH_TASK_1.2_Cultural_diversity_as_an_asset_for human_welfare_a_nd_development [Accessed: Jan. 25, 2015]

[4] Robert J. Stimson, Roger R. Stough, Brian H. Roberts. Regional Economic Development: Analysis and Planning Strategy. Second edition. Springer, 2006.

[5] Keišs S., Kazinovskis A, Regionālā attīstība Latvijā: administratīvi teritoriālās reformas norises gaita, problēmas, risinājumi. Monogrāfija, Rīga, 2014. 
[6] Acta Latgalica 11. Zinotniski roksti, dokumenti, apceris. 11. Sējums. Latgolas Pētniecības institūta izdevniecība. Daugavpils. 2001.

[7] Vanags E., Vilka I., Pašvaldību darbība un attīstība. Rīga: Latvijas Universitātes Akadēmiskais apgāds, 2005.

[8] Nacionālās attīstības plāna 2014.-2020 gadam prioritāšu pamatojuma ziņojums. Pārresoru koordinācijas centrs. Rīga, 2012. [Accessed: March. 7, 2015].

[9] Latvijas Statiskikas gadagrāmata, 2012, Latvijas Republikas Centrālā stattiskikas pārvalde. Rīga, 2013.

[10] Latvijas Statiskikas gadagrāmata, 2013, Latvijas Republikas Centrālā stattiskikas pārvalde. Rīga, 2014.
[11] Zinojums par Latvijas tautsaimniecības attīstību. LR Ekonomikas ministrija. Rīga, 2013

[12] Centrālās statistikas pārvalde. [Online]. Available: http://www.csb.gov.lv/dati/statistikas-datubazes-28270.html [Accessed: March. 14, 2015].

[13] Latvijas regioni skaițos. Statistisko datu krājums. 2005, Latvijas Republikas Centriālā statistikas pārvalde. Rīga, 2005.

[14] Reǵionu attīstības perspektīvas un iespējas. [Online]. Available: $\quad$ http://varam.gov.lv/lat/publ/publikacijas/ reg_att/?doc $=13889$ 